\title{
SOKFÉLE HATVANNYOLCRA EMLÉKEZHETÜNK
}

\author{
PETHÖ LÁSZLÓ \\ ELTE PPK
}

GöTz Aly: Unser Kampf 1968 - ein irritierter Blick zurück. Frankfurt am Main, 2008.

S. Fischer. 253 p. ISBN: 978-3-10-000421-5

Ötven éve Nyugat-Európa-szerte utcára vonultak az egyetemisták, akik több mindennel szemben fejezték ki elégedetlenségüket. Túlnyomó többségük inkább csak hallomásból értesült a háború borzalmairól, sőt mi több, korábban szinte elképzelhetetlen jóléti fordulat részesei lettek. Protestálásuk emléke évfordulós események tárgya lett, különböző, gyakran egymással ellentétes kiindulópontokat és szempontokat követő politológusok, történészek és más társadalomtudósok tettek és tesznek kísérletet egy szinte fogalommá vált évszám, 1968 értelmezésére és magyarázatára.

A 2008-ban megjelent $A$ mi harcunk címü könyv a jelentős feldolgozások egyike. Szerzője Götz Aly, aki maga is részese volt a diákok mozgalmának, egy déli német tartományból, Baden-Württembergből érkezett Nyugat-Berlinbe. Öt mára szakmai körökben jól ismert történészként és publicistaként jegyzik. Neve nálunk is ismert, három könyve mellett több írása és néhány vele készült interjú jelzi jelenlétét. Munkásságának két fö iránya emelhető ki: számos neves német újság szerkesztője és szerzője, de legalább ilyen otthonosan mozog az egyetemi világban és egyéb - föleg a holokauszt történeti forrásaira koncentráló - kutatóhelyeken.
Könyve 12 fejezetben taglalja mondanivalóját, melyet részletes forrásjegyzék és bibliográfia egészít ki. A szerző sokféle forrást - minisztériumi és alkotmánybírósági iratokat, személyes naplókat használt. A kötet tartalmát tükröző névmutató egyik sajátossága, hogy nemcsak a '68-as történések résztvevőit és szereplőit sorolja fel, hanem a német politikatörténet két háború közötti szereplőit ugyanúgy, mint az újonnan egyesült Németország jelentős politikai és tudáselitjének tagjait.

Götz Aly munkájában rekonstruálja a hatvanas évek Nyugat-Németországának gazdasági, politikai és társadalmi folyamatait, amelyek mintegy hátterét képezték a korszak diákmozgalmainak.

$\mathrm{A} z$ országban az ötvenes évek végétől kibontakozó, majd egyre látványosabb és meggyőzőbb eredményeket produkáló gazdasági fellendülés és megerősödés, „csoda” ment végbe. $A z$ utóbbi illusztrálásaképpen a szerző részletesen idéz abból a brosúrából, melyet 1969 májusában, a Köztársaság fennállásnak 20. évfordulója alkalmából jelentettek meg. Az akkor széles körben terjesztett kiadvány adatai szerint az ország elindult a középosztályosodás útján, 9,9\%-ra nőtt a felső középosztály részesedése, látványosan, 0,6\%-ra csökkent a szegények részaránya. A bérek 1949-hez 
képest megnégyszereződtek, tízszeresére nőtt a személygépkocsik száma, még a sörfogyasztás is megnégyszereződött. A gazdaság és a társadalom tehát - némi megtorpanás ellenére - nagyfokú prosperitást és stabilitást mutatott, lényegében megteremtődött és megszilárdulni látszott a jóléti állam.

Lényegesen változékonyabbnak, bonyolultabbnak és kevésbé stabilnak mutatkozott az ország politikai helyzete. Konrad Adenauer kancellár visszavonulásával megszünt a - szociáldemokratákat partnerül el nem fogadó - kereszténydemokrata-konzervatív állandóság. Viszszatekintve azonban kiemelendő, hogy éppen Adenauer kormányzásának kezdeti éveiben, 1947-ben jött létre a Sozialistischer Deutscher Studentenbund (SDS Szocialista Német Diákszövetség), amely megtöbbszörözött funkciójú ellenzéki szervezetként működött. Végeredményben nemcsak a jobboldallal, hanem alapító anyapártjával, a szociáldemokrata SPDvel is gyakorta szembekerült. Az SDS a megalakulását követő években több, egyetemi reformokat követelő és egyéb politikai akciót indított. Tényleges politikai szerephez az 1966-ban megalakult kereszténydemokrata-szociáldemokrata nagykoalíció után jutott. Ennek létrejöttét határozottan ellenezte, így nemegyszer saját pártja és kormánya ellenében politizált. A szerző többször is visszatér arra a tényre, hogy a hatvanas évek közepére az SDS vezetőségében komoly szerepet játszottak az NDK-ból menekültek. Keleten született a diákmozgalmak kulcsfigurája, Rudi Dutschke, de még az ellene 1968-ban merényletet elkövető Josef Bachmann is onnan érkezett.

A diákok számára fontos hátteret jelentettek az egyetemek, közülük is hangsúlyozottan a Nyugat-Berlinben létrejött - más nyugatnémet egyetemektől számos tekintetben eltérő rendben működő
- Freie Universität. Ezen az egyetemen nagyszámú, külföldröl, föleg az USA-ból hazatért oktató tanított, a kedvező tandíjak és a liberálisabb szellem az ország más részeiből is oda vonzotta a hallgatókat. (A szerző saját választását szintén befolyásolta a többi nyugati egyetemtől eltérő müködési rend és szellem.) Az SDS „otthonra” és támogatókra talált a Freie Universtäten, ahol a professzorok közül sokan támogatták a diákok fellépését, de kétkedők és ellenzők is szép számmal akadtak.

Milyenek voltak a diákok? Götz Aly szerint egyre kevésbé fogadták el az Adenauer-éra által kínált ifjúkeresztényi, „habos kávét kortyolgató” modellt. Örültek, ha egy égszínkék Opel volánja mögé ülhettek, és nejlon inget ölthettek magukra. Szüleiknél jobban tolerálták a lezser, lábukat az asztalra feltevő, szájukban folyamatosan gumit rágó „amikat”. Igazán népszerünek a rock and roll, valamint olyan személyiségek, mint Elvis Presley, Marilyn Monroe és John F. Kennedy számítottak köreikben.

Mi vitte őket mégis az utcára, mivel szemben voltak elégedetlenek? Közös jellemzőjük leginkább az antikapitalista hozzáállásuk volt. Idejétmúltnak és korszerütlennek tartották az egyetemek müködését. Nem békültek meg az országuk és vezetői náci múltjával való felemás és következetlen szembenézéssel. Elítélték a gyarmati rendszer felszámolása kapcsán megtapasztalt otrombaságokat. Egyáltalán nem véletlen, hogy a harmadik világ felé igyekeztek tájékozódni, onnan érkező kezdeményezésekből meríteni. Így vált köreikben népszerüvé és követendővé Che Guevara vagy éppen a tömeggyilkos Mao Ce-tung, kulturális forradalmával egyetemben.

Mozgalmuk elindításának szikráját az 1967. június 2-án történtek okozták. A Német Szövetségi Köztársasággal széles 
körű gazdasági kapcsolatot fenntartó Irán vezetője, Reza Pahlavi sah ezen a napon látogatott Nyugat-Berlinbe. A mintegy 4000 diák főleg azért vonult ki tüntetően az Opera előtti térre, mert ki akarta fejezni szolidaritását azzal a tízezernyi emberrel, akiket a sah börtönbe záratott. Fellépésükhöz hozzájárult, hogy az Iránban üldözöttek közül többen a Szövetségi Köztársaságban találtak menedéket. A demonstráció egy túlbuzgó, nem szakszerűen fellépő rendőrnek egy diákra, Benno Ohnesorgra leadott halálos lövése nyomán vérbe fulladt, és ezzel a szellem kiszabadult a palackból.

Sajátos módon alakult a hatalom reakciója. Kurt Kiesinger kancellár június első napjaiban Nyugat-Berlinbe utazott, ahol a rendőrfőnök és a polgármester mellett Rudi Dutschkéval is tárgyalni szándékozott. Akként vélekedett, hogy a gőzt visszaszorítva, egyezségre jut majd „az én szabálytalan fiaim”-mal. Úgy, ahogy az néhány évvel korábban, baden-württembergi miniszterelnöksége időszakában történt. 1967 júniusában azonban az elképzelt találkozó meghiúsult, mert a diákvezér csak teljes sajtónyilvánosság mellett vállalkozott volna egy megbeszélésre.

Ezt követően a diákok, Rudi Dutschke vezetésével, radikalizálódtak, mozgalmuk számos nyugatnémet nagyvárosban talált követőkre. A fiatalok tömegtüntetéseken követelték a felelőtlenül intézkedő rendőrök és parancsnokaik, majd más vezető politikusok leváltását. Korábban jobbára megelégedtek azzal, hogy évente megemlékezzenek az 1953-as kelet-berlini népfelkelés áldozatairól, vagy éppen tüntessenek az NDK-féle "Scheiß-Sozialismus” („szar” szocializmus) ellen. Most már Nyugat-Berlin önálló státusát követelték, azt szerették volna elérni, hogy a város Hongkonghoz hasonló szabad állami státust kapjon.
A törvényeket áthágó diákokkal szemben idővel nemcsak a hatalom lépett fel. Fokról fokra elveszítették a város lakóinak támogatását. Professzoraik is mind megosztottabbá váltak. Változatlanul voltak olyanok, akik rokonszenvüket nyilvánították ki, de növekedett a fejlemények miatt aggódók köre, sőt azok száma is, akik elítélték a diákok cselekedeteit.

A diákok mozgalma az 1968, április 11-i véres esemény, a Rudi Dutschke ellen elkövetett, súlyos következményekkel járó merénylet után újabb fordulóponthoz érkezett, és a protestálások fokozatosan erejüket vesztették, majd megszűntek. Néhány héttel később Párizsban sokkal több, 800000 részvevő - főleg egyetemista - ment ki az utcára változásokat követelve. Franciaországban egy évnek sem kellett eltelnie ahhoz, hogy De Gaulle köztársasági elnök lemondjon. Ezzel együtt korántsem egyértelmü, hogy melyik országot rázta meg jobban a tüntetések sora, hol volt nagyobb hatású a diákok mozgalma.

Götz Aly könyvének azok a fejezetei eredményezték a legnagyobb visszhangot, gerjesztettek széles körben vitákat a kötet megjelenése idején Németországban, amelyek a harminchármasok és a hatvannyolcasok mozgalmát és fellépését állítják párhuzamba. Az apák és fiaik ténykedésének összevetésére alapozott megközelítés közös vonásokat vél felfedezni a fiatalok türelmetlenségében, erőszakosságában és más szélsőségesnek nevezhető állásfoglalásában. Sajtóadatokra és konkrét idézetekre támaszkodva egyöntetűséget láttat abban, ahogyan mind a harminchármasok, mind a hatvannyolcasok élesen támadták koruk nyugalmát és békét preferáló nyárspolgári mentalitását. Ötletszerűnek tűnik azonban a két generáció tudásmonopóliummal szembeni fellépésének egybevetése (értve ezen, hogy mindkét generáció tagjai követelték a tudáshoz 
való tömeges hozzáférés lehetőségének megteremtését). Meghökkentő, de nem meggyőző a náci propagandaminiszter, Goebbels és Dutschke párhuzamba állítása (intoleráns, tudományellenesnek számító álláspontjaik miatt). Érvanyagába a szerző olyan - közvetlenül egyik generációhoz sem tartozó - közéleti szereplök megnyilatkozásait is beemeli, mint Helmut Kohl kereszténydemokrata kancellár, vagy a későbbi pápa, Joseph Ratzinger.

Aly otthonosan mozog a média világában, talán ennek is köszönhető, hogy igyekszik meghökkentő, szokatlan nézöpontból megközelíteni témáját. Időnként azért kiviláglik, hogy otthonosabban érzi magát a náci múlt dokumentumai és forrásai közegében, mint a diákmozgalmak tudományos feltárásában és megközelítésében.

Mára - fél évszázad elmúltával - találó a Die Zeit aktuális évfordulós megemlékezése, miszerint "mindenkinek megvan a maga '68-a'. Az ötven éve lázadó diákok nagy része mára már az aktív tevékenységtől visszavonult nyugdíjas, vagy már nem is él. Aktív korszakukban túlnyomó többségük egyetemeken, szerkesztőségekben, egyéb kutatóhelyeken - és ki tudja még, hol - futott be szakmai karriert. Volt, aki külügyminiszteri posztot vállalt (Joschka Fischer), vagy az Európai Parlament képviselöje lett (Daniel Cohn-Bendit), de olyan is akadt, aki egy ideig bünügyi tudósítások címlapján szerepelt (Ulrike Meinhof).

Reflexióként érdemes még hozzátenni, hogy természetesen Kelet-Európának is megvolt a saját '68-a. A szerző maga is utalásokat tesz a Stasi ügynökeinek beavatkozásaira. Leírja azt is, hogy 1968 augusztusában Nyugat-Berlinben a Prágába való bemasírozás ellen tüntettek. Nem említi viszont azt, hogy az NDK hadseregét mozgósították ugyan, de az végül nem vett részt Csehszlovákia megszállásában: a tartózkodó magatartáshoz feltételezhetően hozzájárultak a Szövetségi Köztársaságban történtek.

A Nyugat-Berlinben és a Szövetségi Köztársaságban zajló eseményekről szóló információkat igyekeztek eltitkolni az NDK polgárai elől. Nemrégiben beszéltem olyan keletnémet kollégával, aki szinte semmit sem tudott felidézni az ötven éve történtekről! Jóval korábban történt a következő eset: egy, az ELTE-n oktató tanár, miután meghívást kapott a Frei Universitäten dolgozó német kollégájától egy Nyugat-Berlinben rendezendő konferenciára, beadta részvételi kérvényét, de a minisztérium csak jóval a konferencia elmúltával járult hozzá kiutazásához. 